\title{
Health, migration and law: what challenges?
}

\author{
Stéphanie Dagron *
}

The reality of migration today is that a large majority of migrants in vulnerable situations either do not have access, or have only very restricted access, to healthcare. While the current importance of the migratory phenomenon and the need to provide protection to disadvantaged migrants has, in recent years, triggered a strong response from the international community in favour of the protection of the rights of persons, either refugees or migrants, fleeing their countries of origin; the central challenge of protecting and promoting the right of migrants to health seems as difficult to as ever. This article firstly sets out the international community's recent political commitments to protect the human rights of migrants as well as the norms of international law applicable to the protection of the health of migrants, mainly contained within international human rights law and international refugee and migrant law. It then discusses the numerous barriers at the national level which block migrants, particularly in vulnerable situations, from accessing care. In doing so, this article highlights the profound paradoxes between State's international commitments on the one hand, and State practices to protect and promote migrant access to healthcare on the other.

I. Introduction 175

II. The political and legal commitment of states in favour of the protection of migrants' rights

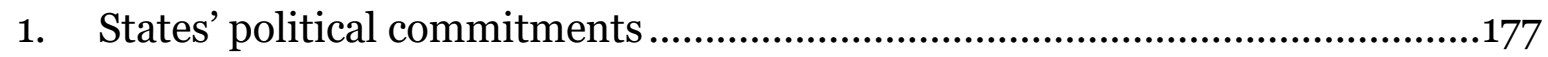

2. States' legal commitments under international law ..................................180

III. Access to health care in migration policies .................................................. 183

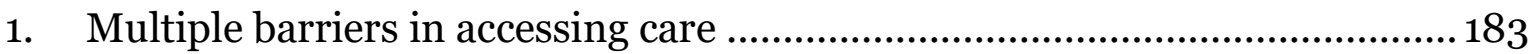

2. Structural and political causes of barriers to access to care ........................ 186

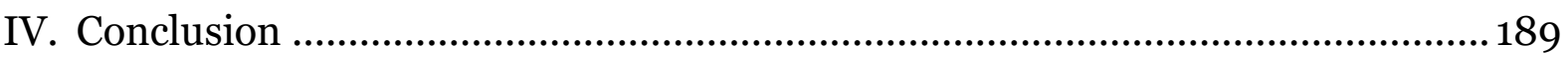

Citation: $\quad$ Stéphanie Dagron, Health, migration and law: what challenges?, in: sui-generis 2019, S. 174

URL: $\quad$ sui-generis.ch/101

DOI: $\quad$ https://doi.org/10.21257/sg. 101

\footnotetext{
* Prof. Dr. iur. Stéphanie Dagron (stephanie.dagron@unige.ch) is a Professor of law at the Univeristy of Geneva. This article is based on an article presented at the annual conference of the University of Neuchâtel's Institute of Health Law in September 2018 and published in Olivier Guillod and Rachel Christinat (eds.), Actes de la 25e Journée de droit de la santé, Mobilité et migration : impact pour le droit de la santé, 2019, pp. 41-68. The author would like to thank M. Angus E.M. Wallace for his translation and assistance throughout the drafting process, as well as Ms. Kasha Caprata for her research on migration more globally. The author is grateful to the Swiss National Sciences Foundation for its financial support.
} 


\section{Introduction}

1 Over the past five years or so, media attention has been called to what has been termed a «migration crisis». Whether it is the "migration crisis» in Europe since 2015, particularly - although not exclusively - related to the situation in Syria ${ }^{1}$, or whether it is the "migration crisis» facing the American continent as a result of the profound political and economic difficulties of some Latin American countries $^{2}$, these «crises» do not accurately reflect the reality of migration in the world over the past decades. Migration should not be considered a punctual phenomenon, intrinsically connected to an armed conflict or a natural, political or economic disaster or crisis. Moreover it does not only affect developed countries. In fact, it has been a constant phenomenon for decades 3 and most interna-

\footnotetext{
See: European Parliament, La crise des migrants en chiffres, 13 July 2017. According to the European Border and Coast Guard Agency (Frontex), in 2015 and 2016, over 2,3 million people have illegally entered the European Union. See: Frontex, News Release: Fewer migrants at EU borders in 2016, 6 January 2017.

2 According to the International Organisation for Migration (IOM), over 1,9 million people have left Venezuela since 2015. See: IOM, Regional InterAgency Coordination Platform for Refugees and Migrants from Venezuela, Regional Response: Situational update No. 1, September 2018. See as well: Organisation of American States (OAS) Permanent Council, Special Meeting to consider the migration crisis stemming from the situation in the Bolivarian Republic of Venezuela, 5 September 2018 (CP/INF.8060/18); OAS, Resolution on the Situation in Venezuela, 5 June 2018; Inter-American Commission on Human Rights, Democratic Institutions, the Rule of Law and Human Rights in Venezuela, 31 December 2017 (OEA/Ser.L/V/II. Doc 209).

3 On the permanent nature of the migratory phenomenon, see in particular: United Nations High Commissioner for Refugees (UNHCR), Report of the UNHCR 1982, 18 August 1982 (A/37/12), $\S \S 1,9$ and 10; UNHCR, Report of the UNHCR 1993, 6 October $1993(\mathrm{~A} / 48 / 12), \S \S 1,132$ and 133.
}

tional migrants reside in developing countries 4 .

2 International law, for its part, has perceived this phenomenon for many decades, developing rules applicable to people in situations of migration. According to the UN, international migrants are defined as «any person who changes his or her country of usual residence», this can be voluntarily or involuntarily, and whether in accordance with national laws or in violation of these laws5.

3 The term 'migrant' thus covers several categories of population. Amongst these we find, first, all people who voluntarily, and legally, left their country of origin in order to work and settle in another country. The first international conventions on migrants were adopted by the International Labour Organization (ILO) in the 1930 s to protect this category of person 6 . They define a migrant worker as someone "who migrates from one country to another with a view to being em-

$4 \overline{\text { According to UNHCR, «85 per cent of refugees }}$ [live] in developing countries» (HCR, Forced displacement above $68 \mathrm{~m}$ in 2017 , new global deal on refugees critical, 19 June 2018). In 2017, the 10 major receiving countries were: Turkey, Pakistan, Uganda, Libya, Islamic Republic of Iran, Germany, Bangladesh, Sudan, Ethiopia and Jordan. See: UNHCR, Aperçu statistique, 19 June 2018.

5 UN Department of Economic and Social Affairs, Statistics division, Recommendations on Statistics of International Migration, 1999, p. 9, § 32.

6 Under its Constitution (Preamble, al. 2), the ILO protects «the interests of workers when employed in countries other than their own». The conditions of this protection are enshrined in the following instruments: Convention No. 66 concerning the Recruitment, Placing and Conditions of Labour of Migrants for Employment, 1939, revised in 1949 (Convention No. 97) and completed in 1975 (Convention No. 143 and Recommendation No. 151); Convention No. 181 concerning Private Employment Agencies, 1997; Convention No. 189 concerning decent work for domestic workers, 2011. 
ployed otherwise than on his own account and includes any person regularly admitted as a migrant for employment» 7 . These people are theoretically subject to the same laws and living conditions as nationals ${ }^{8}$. Migrants also include people who have been forced to flee their country of origin because of persecution, war or extremely dangerous living conditions. Depending on the situation, these persons will be considered as belonging to the categories of refugees, asylumseekers, stateless persons, internally displaced persons or returnees 9 . Persons in these categories are considered particularly vulnerable and their protection has been entrusted to a specialised United Nations agency, the Office of the United Nations High Commissioner for Refugees (UNHCR), established in $1950^{10}$.

4 A final category of persons is constituted of people whose actual need for protection is not recognized by international law and who are therefore not taken into account in the UNHCR's estimates.

\section{ILO, Convention No. 97, art. 11.}

8 On equal treatment, see in particular the International Convention on the Protection of the Rights of all Migrant Workers and Members of their Families (1990), arts. 26, 27 and 28.

9 The 1951 Convention Relating to the Status of Refugees (adopted on 28 July 1951 and entered into force 22 April 1954) defines in its art. 1 as a refugee, any person who has been considered a refugee under previous legal arrangements, as well as any person who «owing to well-founded fear of being persecuted for reasons of race, religion, nationality, membership of a particular social group or political opinion, is outside the country of his nationality and is unable or, owing to such fear, is unwilling to avail himself of the protection of that country (...)». An asylum seeker is a person who is seeking the protection of a State other than his country of nationality, but who hasn't been recognised as a refugee (see UNHCR, UNHCR Global Report 2017, Geneva 2018, p. 238).

10 UN GA, Resolution 428 (V) of 14 December 1950, Statute of the UNHCR, $\S 1$.
These are people who do not meet the requirements of the previous categories and who are in an irregular situation under the applicable immigration legislation ${ }^{11}$. Among these people, there are those who have changed countries on the basis of an official document and who have remained in the country of destination beyond the authorized period. There are also those who have crossed a border without complying with exit or entry rules, or those who have remained in the country of residence after the rejection of an asylum application. Finally, children born to parents in an irregular situation are also included in this category.

5 Ultimately, the expression «migration crisis» is indicative not of the extent of the contemporary phenomenon of migration, but of a change in its nature. According to the International Organization for Migration's (IOM) statistics, the number of international migrants has been constant in relation to the growth of the world's population, even if any slight increase is significant: 152 million international migrants in the world in 1990 (2.9\% of the world population), this rose to 244 million in 2015 (3.3\% of the world population) ${ }^{12}$. What has changed, however, is the number of vulnerable migrants. UNHCR's statistics reveal a real increase in the number of asylum seekers, refugees, stateless persons and displaced per-

11 The ILO defines irregular migrants as «persons who have entered to stay in the country concerned, without fully satisfying the conditions and requirements set by that country for entry, stay or exercise of an economic activity». See: ILO, ILO Global estimates on migrant workers: Results and Methodology - Special focus on migrant domestic workers, Geneva 2015, p. 30.

12 IOM, World Migration Report 2018, table 1, p. 15. 
sons: from 17.5 million people in $1990^{13}$, UNHCR had, in 2017, 71.4 million people placed under its jurisdiction - with the exception of irregular migrants ${ }^{14}$.

6 The «migration crisis» has triggered a strong response from the international community in favour of the protection of the rights of persons, either refugees or migrants, fleeing their countries of origin ${ }^{15}$. Among these rights, the right to the highest attainable standard of physical and mental health is central, and its implementation remains a key challenge for States in terms of health and migration. Guaranteeing this right implies addressing a number of other (sub)challenges, such as access to a health care system that provides timely and appropriate care as well as the fulfillment of other human rights and fundamental determinants of health ${ }^{16}$. As a whole then, States have exhibited a very strong commitment to the protection and the realization of human rights of migrants - including the right to health - irrespective of their status (2). Despite this, the obstacles to the realization of the right to health are numerous, and circumventing them seems particularly difficult given their structural and political origins (3).

$13 \overline{\text { UNHCR, UNHCR population statistics database, }}$ 2017.

14 UNHCR, Global Report 2017 (fn. 9).

15 UN GA, Resolution 71/1 of 19 September 2016, New York Declaration for Refugees and Migrants (A/RES/71/1), § 1. See our analysis below.

16 CESCR, General Comment No. 14, The right to the highest attainable standard of health, 11 August 2000 (E/C.12/2000/4) (GC 14).

\section{The political and legal commitment of states in favour of the protection of migrants' rights}

7 Recent political commitments by States to protect the human rights of migrants (II.1) have come to complement and reinforce weak international legal standards of access to health care (II.2).

\section{States' political commitments}

8 The current importance of the migratory phenomenon and the need to provide protection to disadvantaged migrants has, in recent years, led the international community to increase the protection of migrant health in accordance with their needs. Two recent instruments in particular - the UN's 2030 agenda for sustainable development (II.1.a) and the New York Declaration for refugees and migrants (II.1.b) - illustrate this development.

\section{a) The UN's 2030 agenda for sustainable development}

9 Firstly, the United Nations program for sustainable development adopted in 2015 by the United Nations General Assembly (also called 'the 2030 Agenda') ${ }^{17}$, marks a profound change of paradigm from the Millennium Development Goals (MDGs) ${ }^{18}$. In 2000, neither States nor the UN organizations active in the field of development had connected the concrete consequences of their commitments to the protection of the human rights of migrants and «the fight for development for all the peoples of the world, the fight

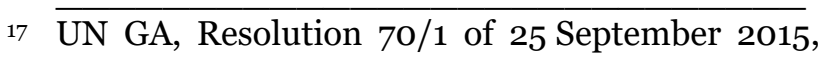
Transforming our World: the 2030 Agenda for Sustainable Development (A/RES/70/1).

18 UN GA, Resolution 55/2 of 13 September 2000, United Nations Millennium Declaration (A/RES/55/2), § VIII. 
against poverty, ignorance and disease; the fight against injustice; the fight against violence, terror and crime»19. Looking back on the progress made since the adoption of the MDGs, the UN Secretary-General noted in 2013 that, in the fight against poverty, it was essential to eliminate the discrimination against migrant populations and the human rights restrictions imposed on them during the various stages of the migration process ${ }^{20}$.

The 2030 Agenda therefore expressly recognizes migration as an essential element of international development and makes the fight for well-managed migration and respect for human rights a crucial goal of the international community. Indeed, this cooperation should aim to «ensure safe, orderly and regular migration involving full respect for human rights and the humane treatment of migrants regardless of migration status, of refugees and of displaced persons» ${ }^{21}$. This crucial commitment to wellmanaged migration fits perfectly with the overall guiding principle of the Agenda to «leave no one behind» in «the collective journey» towards the eradication of «poverty in all its forms and dimen-

19 Ibid., § 25.

20 UN, Report of the Secretary-General, A life of dignity for all: accelerating progress towards the Millennium Development Goals and advancing the United Nations development agenda beyond 2015, 26 July 2013 (A/68/202), § 93.

21 UN 2030 Agenda (fn. 17), § 29. See also Objective 10.7: «Facilitate orderly, safe, regular and responsible migration and mobility of people, including through the implementation of planned and well-managed migration policies. Other objectives explicitly deal with migration». See Objective 8.8: «Protect labour rights and promote safe and secure working environments for all workers, including migrant workers, in particular women migrants, and those in precarious employment.» sions» ${ }^{22}$. The 17 SDGs must therefore be achieved by all, especially the most vulnerable people who need special support to benefit from progress and development. This clarification is essential, and it applies to all the objectives, and in particular Objective 3 which concerns the good health and well-being of all at any age.

\section{b) The New York Declaration for Refugees and Migrants of 19 September 2016}

11 The second document which embodied the UN's 2015 commitment to the protection of migrants took the form of a declaration for refugees and migrants. Adopted in September 2016 in New York by the 193 Member States of the United Nations, this Declaration sets out the terms of the international community's joint response to the massive movements of people around the world caused by, inter alia: armed conflicts, poverty, food insecurity, persecution, terrorism, massive violations and abuses of human rights, climate change, natural disasters or other environmental factors ${ }^{23}$. According to this text, protecting the fundamental rights of all persons forced to flee their country of origin and assisting the host countries and communities concerned, are shared international responsibilities and must be assumed in an equitable

22 Ibid., preamble. See on this point: C. Brolan, S. Dagron, L. Forman, R. Hammonds, L. Abdul Latif, A. Waris, Health Rights beyond Borders: Including Non-Nationals in the Post-2015 Development Agenda, Bulletin of the World Health Organization, 91 (2013) 10; C. Brolan, S. Dagron, L. Forman, R. Hammonds, L. Latif, A. Waris, The right to health of non-nationals in the Sustainable Development Goals era: Challenges for equity in universal health care, International Journal for Equity in Health, 16 (2017) 14.

23 New York Declaration (fn. 15), § 1. 
manner ${ }^{24}$. Health protection involves taking into account both the specific needs of refugees and migrants and, in particular, the health needs of women and children ${ }^{25}$, as well as the development of health systems so that care is provided in the community and, as far as possible, by national and local providers ${ }^{26}$.

Migrants have many specific health needs and, indeed, require appropriate care to deal with them. These needs vary during the different phases of migration ${ }^{27}$. During the phases of travel and arrival in the country of destination, phases which are characterized by high rates of mortality and morbidity, free emergency services are required ${ }^{28}$. Mortality declines however, in subsequent phases of installation and integration. The health status of migrants then depends on the conditions of access to care, socio-economic living conditions and, finally, the conditions of integration (work, education for children, etc.) ${ }^{29}$. During the installation phase, emergency needs must be met and additional care such as psycho-social and reproductive health

24 Ibid., § 11.

25 Ibid., §§ 30, 31, 32, 39, 59, 80 as well as Annex I and II.

26 Ibid., Annex I, § 7b.

27 On the different phases of migration and the specific health needs of migrants, see: UNHCR, Global Strategy for Public Health: a UNHCR Strategy 2014-2018, Geneva 2014; UNHCR, Public Health and HIV section's Guiding Principles and Strategic Plans for 2008-2012, Geneva 2008; Médecins du Monde, L'accès aux soins des personnes confrontées à de multiples facteurs de vulnérabilité, May 2015.

28 Jorge Bustamante, Migration and health. A human rights approach, in: WHO, Health of Migrants: The way forward, Report of a global consultation, Madrid, Spain, 3-5 March 2010, 2010, keynote addresses, pp. 89-94.

29 Ibid., p. 90. care is needed $3^{\circ}$. During the integration phase, continuity of care is essential and the treatment of chronic diseases must be ensured. Health needs are thus more diverse and it is necessary to provide additional interventions as well as to develop an appropriate funding system for care 31.

13 Health needs vary further according to the age and gender of individuals, as well as their socio-economic living conditions. Migrant populations of young adult males do not have the same health needs as migrant populations made up of complete families, that is: elderly people, people with disabilities, people with chronic diseases, children or pregnant women32. Beyond this, needs vary according to the conditions of movement of migrants and their living conditions in the destination country33. In this respect, the epidemiological studies are clear: Migration can be beneficial for health when it is voluntary and properly regulated. On the other hand, migration will be a threat to people's health when it is coerced, when it encounters restrictive or even repressive regulations and when the living conditions in the country of destination because of the status of asylum seekers, refugees or irregular migrants - are extremely difficult and marked by discrimination, insecurity, exclusion, dangerousness of work or exploitation 34 . $\begin{array}{ll}30 & \text { Ibid., p. } 90 . \\ 31 & \text { Ibid., p. 90. } \\ 32 & \text { Ibid., p. 90. } \\ 33 & \text { Ibid., p. 90. } \\ 34 & \text { Ibid., p. 90. }\end{array}$ 


\section{States' legal commitments under international law}

14 The norms of international law applicable to the protection of the health of migrants are manifold. They mainly concern international refugee and migrant law (II.2.a) and international human rights law (II.2.b).

\section{a) International refugee and migrant law}

International refugee and migrant law is composed of binding standards that contain few health-related provisions, and non-binding standards that contain much more specific provisions on the protection of refugees' and migrants' health and their access to medical care. These binding instruments include, firstly, the 1951 Convention relating to the status of Refugees and the 1954 Convention relating to the status of Stateless Persons. These Conventions provide only for States to grant «to refugees lawfully staying in their territory the same treatment with respect to public relief and assistance as is accorded to their nationals»35. Secondly, the International Convention on the Protection of the Rights of all Migrant Workers and Members of their Families, adopted in 1990, contains an obligation to provide emergency care. According to Article 28, «[m]igrant workers and members of their families shall have the right to receive any medical care that is urgently required for the preservation of their life or the avoidance of irreparable harm to their health on the basis of equality of treatment with nationals of the State concerned». This

1951 Convention (fn. 9), art. 23; Convention Relating to the Status of Stateless Persons, adopted 28 September 1954, entered into force 6 June 1960, art. 24. convention is interesting in that it applies to all workers, regardless of whether they are in a regular or irregular situation under the law of the country of residence ${ }^{36}$. It is thus specified that emergency medical care cannot be refused to migrant workers «by reason of any irregularity with regard to stay or employment» 37 . This said, not only has this convention not had the expected impact so far due to the limited number of States that have agreed to ratify it, as well as the numerous obstacles to its implementation 38 , but also the concrete obligations that it contains in terms of health matters remain extremely limited in scope. In reality, emergency care is only care that cannot wait due to the imminent danger to the life or health of those concerned. For example, emergency care is defined in the French social code as care «whose absence would be life-threatening or could lead to serious and lasting deterioration of the person's health» 39 . It is therefore much more limited in scope than primary health care, the latter being considered essential for the realization of the right to health 40 .

16 Non-binding instruments adopted since the end of the 1990s are more demanding with regard to access to health care for migrants. For instance, in 1998, the Commission on Human Rights adopted

1951 Convention (fn. 9), art. 1 and 4

37 Ibid., art. $28 \S 2$.

38 See the following analysis: Antoine Pecoud and Paul De Guchteneire, Migration, human rights and the United Nations. An investigation into the obstacles to the UN Convention on migrant workers' rights, Windsor Yearbook of Access to Justice, 24 (2006) 2, pp. 241-266.

39 Code français de l'action sociale et des familles, art. L254-1 (translation: author's own).

40 On the distinction between emergency healthcare and primary health care, see the analysis below at II.2.b. 
the «Guiding Principles on Internal Displacement» 41 . According to these principles, States should establish at a minimum essential medical services and sanitary facilities in all circumstances and without discrimination42; they must also provide to «all wounded and sick internally displaced persons as well as those with disabilities (...), the medical care and attention they require», such as «psychological and social services»43. These clarifications are interesting even if the formulations retained leave States, in the end, an important margin of manoeuvre. Indeed, care must be provided «as far as possible and as soon as possible» and only «special attention» is required with regard to women's care, including reproductive and sexual health, and the prevention of communicable diseases 44 .

More recent soft law instruments however, reflect a broader approach to refugee and migrant health protection. This is true of UNHCR's 2014-2018 Global Strategy, which provides an extensive interpretation of Article 23 of the Refugee Convention45. This is also true of the two global compacts adopted by the international community to implement the commitments of the New York Declaration mentioned above. The 2018 Global Compact for Safe, Orderly and Regular Migration ${ }^{46}$ signed in December 2018 in

41 UNHCR, Guiding Principles on Internal Displacement, 16 October 1998 (E/CN.4/1998/53/Add.2).

42 Ibid., Principle 18.

3 Ibid., Principle 19, § 1.

4 Ibid., Principle 19, §§ 2 and 3.

45 UNHCR, Global Strategy for Public Health 20142018 (fn. 27), p. 12.

46 See: Global Compact for Safe, Orderly and Regular Migration (Global compact on migration), Draft outcome document of the Conference, 30 July 2018 (A/CONF.231/3).
Marrakech 47 and the Global Compact on Refugees, presented in November 2018 to the United Nations General Assembly ${ }^{4}$, clarify the nature of the national and international efforts required in relation to health. Recognizing that both migrants and refugees enjoy human rights, irrespective of their migratory status, and regardless of the phase of the migration in which they find themselves, these two covenants place special emphasis on two objectives: on the one hand, to take into account the health needs of migrants 49 and refugees5o, which means that medical care cannot be limited to emergency care; while on the other, ensuring the strengthening of national health systems. In accordance with the Global Compact for Migration, this second objective is to be achieved by «strengthening capacities for service provision, facilitating affordable and non-discriminatory access, reducing communication barriers, and training health-care providers on culturally sensitive service delivery, in order to promote the physical and mental health of migrants» 51 . In the context of refugee protection, it is similarly stated that it is essential «to build and equip health facilities or strengthen services $\gg 5^{2}$, to encourage «[d]isease prevention, immunization services, and health promotion activities» 53 and to facilitate «affordable and equitable access to adequate quantities of

$47 \overline{\mathrm{UN}, \text { Intergovernmental Conference on the Global }}$ Compact for Migration, 11 December 2018.

48 UNHCR, Report of the UNHCR, Part II, Global compact on refugees (Global compact on refugees), 2018 (A/73/12-Part. II).

49 Global Compact for Migration (fn. 46), Objective 15.

50 Global Compact on Refugees (fn. 48), Point III.B.2.

51 Global Compact for Migration (fn. 46), Objective 15.

52 Global Compact on Refugees (fn. 48), § 73 .

53 Ibid. 
medicines, medical supplies, vaccines, diagnostics, and preventive commodities»54.

\section{b) International human rights law}

The contemporary interpretation of the obligations on States deriving from international refugee and migrant law 55 is explicitly based on international human rights law and on the more recent embodiment of the right to the highest attainable state of physical and mental health. This right is enshrined in many international conventions, such as the International Covenant on Economic, Social and Cultural Rights56, the International Convention on the Elimination of All Forms of Racial Discrimination57, the Convention on the Elimination of All Forms of Discrimination against Women ${ }^{5}$, the International Convention on the Rights of the Child59 or the International Convention on the Rights of Persons with Disabilities $^{60}$. The analysis of these conventions shows that the right to health must be guaranteed to all without exception and that States are also under a number of more specific obligations in relation to access to health care services.

54 Ibid.

55 UNHCR, Global Strategy for Public Health 20142018 (fn. 27).

56 ICESCR, art. 12.

57 International Convention on the Elimination of All Forms of Racial Discrimination (ICERD), UN GA, Resolution 2106 A(XX), 21 December 1965, art. 5 e) iv).

58 Convention on the Elimination of All Forms of Discrimination against Women (CEDAW), UN GA, Resolution 34/180, 18 December 1979, art. 12.

59 Convention on the Rights of the Child (CRC), UN GA, Resolution 44/25, 20 November 1989, art. 24 .

60 Convention on the Rights of Persons with Disabilities (CRPD), UN GA, Resolution 61/106, 13 December 2006, art. 25.
19 Indeed, no distinction should be made between nationals and non-nationals. The International Covenant on Economic, Social and Cultural Rights (ICESCR) thus guarantees the right of «every person» to health ${ }^{61}$ and the other texts guarantee the same right of everyone «regardless of race, color, national or ethnic origin» 62 . The Committees in charge of the implementation of the Conventions also insist on the obligation for States to be very attentive to the protection of «asylum seekers and illegal migrants» 63 . For the Committee in charge of implementing the ICESCR (CESCR), there is no doubt that «the Covenant rights apply to everyone including non-nationals, such as refugees, asylum-seekers, stateless persons, migrant workers and victims of international trafficking, regardless of legal status and documentation» 64. The Committee on the Rights of the Child, for its part, considers that special attention should be given to «the particular challenges to children's health for children affected by humanitarian emergencies, including those resulting in large-scale displacements due to natural or man-made disasters» 65 .

61 ICESCR, art. 12 al. 2 d.

62 CERD, art. 5. See as well, art. 12 (1) CEDAW, or art. 24 CRC.

63 CESCR, GC 14 (fn. 16), § 34; Committee on the Elimination of Racial Discrimination (ICERD), General recommendation No. 30 on discrimination against non-citizens, 19 August 2004, § 29; Committee on the Elimination of Discrimination against Women (CEDAW), General recommendation No. 26 on women migrant workers, 5 December 2008 (CE-DAW/C/2009/WP.1/R).

64 CESCR, General Comment No. 20 on Nondiscrimination in economic, social and cultural rights, 2 July 2009, § 30.

65 See: Committee on the Rights of the Child, General Comment No. 15, on the right of the child to the enjoyment of the highest attainable standard of health, 17 April 2013, § 40. 
Secondly, international human rights law provides information on the obligations on States to create the «conditions which would assure to all medical service and medical attention in the event of sickness» 66 . With regard to the obligation to ensure access to health care, any hesitation between emergency care and more comprehensive care is removed by reading the CESCR's General Comment 14 on the right to health, adopted in 2000. In general, the realization of the right to health - which should not be understood as a right to be in good health - extends «not only to timely and appropriate health care but also to the underlying determinants of health» 67 , such as access to safe and potable water and adequate sanitation, safe food, or even occupational health, education and information related to health ${ }^{68}$. Although not all these benefits must be realized immediately ${ }^{69}$, it is clear from the interpretation developed by the CESCR that States are under a basic minimum obligation to provide primary health care, as defined in the Alma Ata Declaration adopted in 1978, for all and without delay. In accordance with this Declaration, primary health care is care intended to address «the main health problems in the community, providing promotive, preventive, curative and rehabilitative services accordingly»70. Primary care is, consequently,

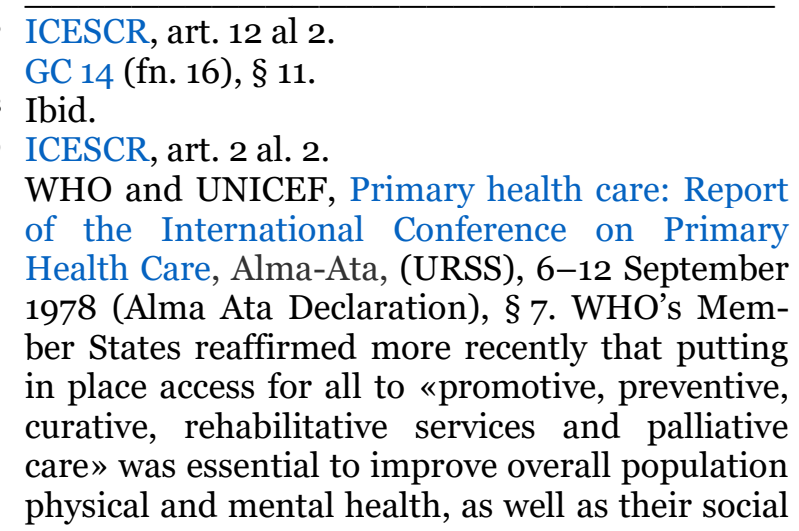
of the International Conference on Primary Health Care, Alma-Ata, (URSS), 6-12 September 1978 (Alma Ata Declaration), § 7. WHO’s Member States reaffirmed more recently that putting in place access for all to "promotive, preventive, curative, rehabilitative services and palliative care» was essential to improve overall population physical and mental health, as well as their social

more broad and comprehensive than emergency care: it includes, inter alia, reproductive health care, maternal and child health, vaccination against major infectious diseases, prevention, treatment and control of epidemic and endemic diseases ${ }^{71}$.

\section{Access to health care in migration policies}

21 At the national level, there are numerous barriers to access to care that particularly affect migrants in vulnerable situations (III.1), and these barriers to access stem from structural and political causes (III.2).

\section{Multiple barriers in accessing care}

22 The analysis of national laws applicable to the health of migrants is a difficult undertaking, the conditions of access to care being extremely variable from one country to another (III.1.a). However, commonalities are identifiable, especially regarding the issue of access to care for the most vulnerable migrants (III.1.b).

\section{a) Access to health care: heteroge- neity of situations}

23 Many reports offer a comparative analysis of the conditions of migrant access to care and national legislations around the world 72 . These reports tend to agree that access to health care is extremely varia-

wellbeing. See: WHO and UNICEF, Declaration of Astana, 25 and 26 October 2018 (WHO/HIS/SDS/2018.61).

71 GC 14 (fn. 16), §§ 43 and 44.

72 See in particular the following Reports: WHO, World Health Report 2005, Geneva 2005; Médecins du Monde, 2015 (fn. 27); Médecins Sans Frontières, Access to healthcare for people facing multiple vulnerability in health in 31 cities in 12 countries, 2016. On the situation in Europe, see: 
ble from one country to another and depends on the legal status of migrants 73 . This access may be the same for nationals and regular migrants permanently installed in a country in which universal health coverage is a reality. On the other hand, such access will either be nonexistent or limited to emergency care for irregular migrants. Between these two extremes, irregular migrants, asylum seekers and refugees may also be able to access care that is considered necessary or essential, although different from that for nationals but equivalent to primary health care, including prevention, rehabilitation and even dental and mental health.

24 The analysis of the issue of access to care in the European Union (EU) Member States confirms both the great heterogeneity of national situations and the limited access in general for migrants in the EU in situations of vulnerability 74 . The European Parliament noted in a resolution adopted in 2014 on undocumented

IOM Healthcare for Undocumented Migrants in the EU: concepts and cases, 2009; European Observatory on Health Systems and Policies, Migration and health in the European Union, 2011; European Union Agency for Fundamental Rights, Migrants in an irregular situation: access to healthcare in 10 European Union Member States, 2011.

73 See in this sense: WHO 2005 Report (fn. 72), p. 21; European Union Agency for Fundamental Rights (fn. 72), p. 17; UNHCR, Global Strategy for Public Health 2014-2018 (fn. 27), p. 9.

74 This heterogeneity is explained by the fact that within the European Union, States have maintained a large part of their sovereignty in terms of health policy, and healthcare organisation. Indeed, the EU only has a complementary competence, and in some situations a shared competence. See: The Treaty on the Functioning of the European Union (TFEU), art. 168. migrant women in the European Union 75 that «access to the most basic healthcare services, such as emergency care, is severely limited, if not impossible»76. The same conclusion can be drawn regarding asylum seekers. The European Union has imposed some constraints on States through Directive 2013/33/EU of 26 June 2013 laying down standards for the reception of applicants for international protection 77. According to this instrument, States must «ensure that applicants receive the necessary health care which shall include, at least, emergency care and essential treatment of illnesses and of serious mental disorders» 78 and, «provide necessary medical or other assistance to applicants who have special reception needs»79. However, these obligations are not binding and, not only is there no definition of necessary care, emergency care or medical assistance, but States still have the possibility to subordinate the granting of health care to the financial participation of asylum seekers ${ }^{80}$. Again, the vagueness of these obligations leaves States more policymaking flexibility and migrants therefore have more or less limited access to care according to the country of destination and according to their legal status ${ }^{81}$.

$75 \overline{\text { European Parliament, Resolution of } 4 \text { February }}$ 2014 on undocumented women migrants in the European Union (2013/2115[INI]), § A.

76 Ibid., § M.

77 Directive 2013/33/UE of the European Parliament and of the Council of 26 June 2013 laying down standards for the reception of applicants for international protection, Official Journal of the European Union, L 180, 29 June 2013, pp. 96-116.

78 Ibid., art. 19, al. 1.

79 Ibid., art. 19, al. 2.

80 Ibid., art. 17, al. 3 and 4.

81 On the heterogeneity of situations in Europe, see the analysis of the European Union Agency for Fundamental Rights (fn. 72). 


\section{b) Barriers to access to care for the most vulnerable migrants in Europe}

Examples of legislative provisions that constitute barriers to access to health care are numerous and generally, but not exclusively, concern persons in irregular situations. These barriers can be direct when they take the form of conditions for access to care. This is the case when access is conditioned on a minimum period of residency in the destination State. In 2003, the European Committee of Social Rights $^{82}$ considered that the residency requirement of three months imposed on migrants in France before allowing access to care other than emergency care was contrary to art. 17 of the Charter which protects the right of children to "grow up in an environment which encourages the full development of their personality and of their physical and mental capacities» 83 .

This is also the case when access to care is conditioned on the patient paying full or partial fees for care. In 2006, the Special Rapporteur on the right to health found that the obligation of full payment of health care, including emergency care, imposed by Swedish law on irregular migrants was contrary to the right to health as guaranteed under the ICESCR ${ }^{84}$. Finally, a direct obstacle can also result

$82 \overline{\text { European Committee of Social Rights, The Inter- }}$ national Federation of Human Rights Leagues (FIDH) v. France, Complaint No.14/2003, Decision of 8 September 2004.

83 Council of Europe, European Social Charter (Revised), 3 May 1996, STCE 163, art. 17.

84 UN GA, Human Rights Council Report of the Special Rapporteur on the right of everyone to the enjoyment of the highest attainable standard of physical and mental health, Paul Hunt, mission to Sweden, 28 February 2007 (A/HRC/4/28/ Add. 2), § 37. from the existence of overcomplex administrative procedures. In Belgium, for example, the conditions of access to preventive and curative care covered by Urgent Medical Assistance (AMU) for persons residing illegally 85 , have been considered as leading to unfair access to such care ${ }^{86}$. In accordance with the applicable rules, the award of the AMU is in fact conditioned by an administrative inquiry which may be long and complex. In particular, this inquiry must determine, on the one hand, whether the person illegally residing has sufficient means of subsistence to ensure a life in dignity, in which case they will not be able to benefit from the AMU and, on the other hand, if urgent medical care is required, the urgency must be attested by a medical certificate.

Limitations to access are, however, indirect when the measures adopted, while not directly addressing healthcare do, as a result, impact on access to healthcare. Such limitations exist, for example, when irregular migrants go without medical care for fear of being reported to the immigration authorities. In many States, these fears are well-founded, as States impose an obligation of cooperation between health care and immigration services, or delay defining precise rules prohibiting this cooperation ${ }^{87}$. In both cases, trust in health services is diminished.

$85 \overline{\text { Arrêté royal relatif à l'aide médicale urgente oc- }}$ troyée par les centres d'aide sociale aux étrangers qui séjournent illégalement dans le Royaume (Belgium), 12 December 1996, art. 1.

86 See generally the following Report of the Belgian Health Care Knowledge Centre (KCE): KCE, Quels soins de santé pour les personnes en séjour irrégulier? KCE Report 257Bs, 2015 (www.kce.fgov.be), p. 20.

87 One study of the applicable legislation in $33 \mathrm{Eu}-$ ropean countries, done by the IOM, found that 
Recent regulatory developments in the United Kingdom clearly illustrate the progressive weakening of the barrier between health and immigration services. In 2005, the United Kingdom introduced an obligation for health professionals to provide non-medical information requested by the immigration authorities 88 . Since 2017, the effectiveness of the transmission of this information has been strengthened by the adoption of a «Memorandum of Understanding» between the Ministry of Health and the Ministry of the Interior ${ }^{89}$. This text requires the Ministry of Health to transmit information about patients in the national public health system as collected and digitized by the national center for patient data collection (National Information Center, NHS Digital). The requested information is not medical information, it is information used to find individuals: addresses of suspected individuals, dates of birth, names, registration numbers within the health system, nationalities, names and addresses of their general practitioners.

The agreement between the Ministry of the Interior and the Ministry of Health

only 10 countries explicitly prohibited information transfers, 6 required such transfers, and 18 did not legislate on the question, leaving migrants, as well as healthcare personnel in uncertain positions. See: IOM, Summary Report on the MIPEX Health Strand and Country Reports, IOM Migration Research Series No. 52, 2016, p. 66.

88 See section 261 (5) Health and Social Care Act 2012 which provides for the transfer of information when it is necessary for the protection of the concerned individual (c) or when the information is required for a criminal investigation (e).

89 UK Department of Health and Social Care and UK Home Office, Memorandum of understanding between health and social care information centre and the home office and the department of health, 24 January 2017. has been strongly criticized by civil society and professional associations 90 as well as by those in charge of controlling the collection or use of medical data ${ }^{11}$. Critics point out the negative consequences of such a practice: fear of identification and expulsion firstly results in the renunciation of health care at the prevention or treatment phases, which can lead to the use of emergency services further down the line ${ }^{92}$. Another consequence is the possible use by individuals of the identity of other persons not in an irregular situation and the discontinuity of medical information concerning these persons 93 .

\section{Structural and political causes of barriers to access to care}

30 Multiple causes that are both structural (III.2.a) and political (III.2.b) explain the wide variability in the conditions of access to care for migrants around the world.

\section{a) Structural causes: the hetero- geneity of health systems}

31 In 2000, the WHO reported in its World Health Report that resources devoted to health systems in developing countries were extremely limited, despite $84 \%$ of the world's population and $93 \%$ of the

90 Daynes L, Azad Y, Carlin E, et al., The NHS should protect patient confidentiality, The Guardian, 27 January 2017.

91 See: Koldo Casla, Peter Roderick, Allyson M Pollock, Disclosure of patients' data to the UK Home Office must stop, Editorials, BMJ 358 (2017), p. j3613.

92 See: Just Fair, Doctors of the World, Right to health for all: why the Home Office should not have access to NHS patients' data, and why NHS professionals should not be expected to guard our borders (if we are to take human rights seriously), 2017.

93 See the references in: Anne Gulland, Handing NHS data to the home office, BMJ 56 (2017), p. j911. 
world's global burden of disease being there 94 . The consequences of this weakness of resources are visible through the difficulties of access to essential drugs or essential medical services, which are key elements of health systems95. Beyond this, the health systems of low-income countries are characterized by a shortage of health personnel 96 and the lack of an appropriate funding system for care, with patients being forced to pay the costs of care and treatment directly97. Despite clear progress in the development of care and treatment for several years ${ }^{98}$, the figures reported by the WHO have not changed significantly since 2000. Thus, more than half of the world's population does not benefit from health coverage allowing access to essential health services 99 . The ILO has confirmed this analysis. In its report on global social protection published in 2015, it highlighted disparities between developed and developing countries in access to health care $^{100}$. This report showed that $80 \%$ of the population in low-income countries lack adequate access to essential health services because of both the weakness of

94 OMS, The World Health Report 2000: Health systems: improving performance, Geneva 2000, p. 8.

95 On the definition of health systems, see: WHO, Everybody's business: strengthening health systems to improve health outcomes, Geneva 2007, p. 2.

96 WHO and Global Health Workforce Alliance, A universal truth: no health without a workforce, 2014, p. 26, Fig. 8.

97 WHO, World Health Report, Health systems financing: The path to universal coverage, Geneva 2010, p. 45.

98 Ibid., p. 23.

99 See the following Reports: WHO, World Health Report 2010, ibid.; WHO, World Bank, Tracking universal health coverage, First global monitoring report, 2015, pp. 20-21.

${ }^{100}$ ILO, World social protection report 2014-15, building economic recovery, inclusive development and social justice, Geneva 2014. available health services and the lack of an insurance system or state funding scheme to cover the costs of health care ${ }^{101}$.

32 Access to care for disadvantaged migrants in developing countries that do not provide access to basic health services for their population is therefore illusory. The international community seems recently to have become aware of the need to strengthen the health systems in all their components in order to promote the health of all without distinction of nationality ${ }^{102}$. UNHCR has also been insisting on this point for a few years as it has been faced with the ethical problems of allocating more comprehensive health care in refugee camps than the health care available and accessible to the national population. This said, UNHCR notes generally that there are inequalities in access to appropriate curative and preventive health care for refugees on the one hand and the local population on the other. It is not uncommon for it to ensure that the level of health care provided for populations close to refugee assembly areas is improved ${ }^{103}$. The strategy adopted in 2014 is therefore aimed at the development of national health systems. Its aims are to enable refugees and host populations to access comparable services and to avoid the development of unsustainable parallel systems ${ }^{104}$.

\footnotetext{
101 Ibid., p. 103.

102 See for example: WHO, Joint United Nations statement on ending discrimination in health care settings, 27 June 2017.

103 See in this regard: UNHCR, Public Health Equity in Refugee and Other Displaced Persons Settings, April 2010, pp. 12-13.

104 UNHCR, Global Strategy for Public Health 20142018 (fn. 27), pp. 13.
} 


\section{b) Political causes: access to care for migration policies}

33 In developed countries, political reasons lie behind barriers to access to health care for migrants, including irregular migrants. In many countries, access to care will depend on political strategies developed not according to the health needs of migrants, but in terms of migration policy choices. Contemporary migration policies in high income countries, despite States' commitments to the protection of the rights of migrants, are increasingly restrictive. With one hand, States adopt conventional security measures aimed at restricting the mobility of individuals ${ }^{105}$, while with the other, they adopt measures affecting the socioeconomic living conditions of individuals, including measures relating to access to health care. As a whole, the purpose of these policies is to discourage international migrants from settling in their territory or to encourage those already present to leave voluntarily. There are many examples of this, and the links between migration policy and direct or indirect barriers to access to care have been criticized by non-governmental human rights organizations, the academic world, public institutions, and the courts.

34 For example, in France, the Comite consultatif national d'éthique (National consultative ethics committee), stated in an opinion issued in October 2017 that migrants' access to care was insufficient ${ }^{106}$, recalling that «from an ethical point of

$105 \overline{\text { See: Laurence Burgorgue-Larsen, Les injonctions }}$ contradictoires en matière migratoire, Revue des droits et libertés fondamentaux, (2018) chron. 17, pp. 2-3.

106 Comité consultatif national d'éthique, Santé des migrants et exigence éthique, avis No.127, 16 October 2017, p. 19. view, when it comes to any person in distress, the question of health (...) must in no case be instrumentalized»107. The Committee added that «in the case of migrants, [this question] cannot be used as part of a policy of discouragement and refoulement ${ }^{108}$.

35 In Canada, the Federal Court of Appeal in 2014 denounced the use by public authorities of the issue of access to health care in the service of its new migration policy. The Court was asked about the compliance of the 2012 amendments to the federal health program with the Canadian Charter of Rights and Freedoms ${ }^{109}$. These changes led to a reduction in the coverage of care previously provided free of charge to disadvantaged migrants (refugees, asylum seekers and migrants in situations of high vulnerability) ${ }^{110}$. The Court clearly criticized the fact that these amendments, which particularly affected migrants in vulnerable situations, served as part of a particularly restrictive migration policy. For the Court, the sole purpose of these amendments was to make the lives of people in vulnerable situations even more difficult, in accordance with a policy which aimed both to discourage migrants from seeking refuge in Canada and to encourage migrants to voluntarily leave the country ${ }^{111}$. The Court accordingly considered that

107 Ibid., p. 23 (translation: author's own).

108 Ibid., p. 23 (translation: author's own).

109 Canadian Federal Court of Appeal, Canadian Doctors for Refugee Care v Canada (AG), 2014 FC 65 .

110 Ibid., p. 6. On the substantive aspects of these modifications, see as well: Ethan Holtzer, Aliia Moore-Dean, Amirrtha Srikanthan and Kerry Kuluski, Reforming refugee healthcare in Canada: Exploring the use of policy tools, Healthcare Policy, 12 (2017) 4, pp. 46-55.

111 Canadian Doctors for Refugee Care v. Canada (fn. 109), § 690 . 
these measures constituted a violation of the Charter which prohibits cruel and unusual treatment or punishment and that, therefore, they had no legal effect ${ }^{112}$.

36 Finally, the United Kingdom has, since 2012, adopted many measures that limit access to care for migrants as a whole. These measures are part of an immigration policy developed since 2012 which aims to reduce the number of immigrants to the United Kingdom ${ }^{113}$. In 2012, Theresa May, then Home Secretary, explained the strategy as follows: «The aim is to create in Britain a really hostile environment for illegal migration (...). What we do not want is a situation where people think they can come here because they are able to access everything they need»114. The 2017 «Memorandum of Understanding» which required the exchange of non-medical information between the health and immigration services $^{115}$, was consequently concluded in order to achieve the following policy objectives: reduce the number of irregular migrants, reduce the negative impact of illegal immigration in the UK, increase the number of expulsions, contribute to the elimination of immigration-related crimes, and increase the number of irregular migrants leaving the $\mathrm{UK}^{116}$. The

112 Ibid., p. 266.

113 Other measures touch on the conditions to access work or housing, on the possibility of appealing the decisions of the Home Office. See: House of Lords, Impact of 'Hostile Environment' Policy Debate on 14 June 2018, Library Briefing 11 June 2018; House of Commons, Home Affairs Committee, 'Immigration policy: basis for building consensus', Second report of Session 2017-19, p. 20.

114 Kirkup and Winnett, Theresa May interview: 'We're going to give illegal migrants a really hostile reception', Telegraph, 25 May 2012

115 See fn. 89.

116 Ibid., Point 4.2 impact of these measures on the health of migrants in vulnerable situations has been the subject of recent analysis and criticism $^{117}$. For instance, the UK's national human rights institution - the Equality and Human Rights Commission $^{118}$ - asked the government to clearly separate immigration policies from access to health in order for UK Public Health Services ${ }^{119}$ to be accessible to all migrants regardless of their legal status ${ }^{120}$.

\section{Conclusion}

37 The central challenge of protecting and promoting the right of migrants to health - which itself includes many (sub-) challenges - seems difficult to achieve at present, as a large majority of migrants in vulnerable situations either do not have access, or have only very restricted access, to healthcare. A number of different reasons for this have been identified. Among these, the use of access to healthcare as an element of restrictive migration policies is a practice which seems particularly hard to combat as the applicable international refugee and mi-

117 Equality and Human Rights Commission (UK), The lived experiences of access to healthcare for people seeking and refused asylum, Research report 122, November 2018, p. 39.

118 Equality Act 2006 (UK), Part 1.

119 The Welsh and Scottish governments adopted a different approach to irregular migrant access to healthcare. See: Scottish Government, New Scots: refugee integration strategy 2018 to 2022, 2018; Welsh Government, Nation of sanctuary - Refugee and asylum seeker plan, 2018.

120 Equality and Human Rights Commission (UK), Making sure people seeking and refused asylum can access healthcare: what needs to change? Research report 121, November 2018, p. 9. See also the following criticisms: Doctors of the world, UK's human rights regulator calls for 'clear separation' between immigration policies and healthcare, 29 November 2018. 
grant health norms are imprecise and incomplete.

38 This being said, it is possible to criticise State practices in the light of international human rights law. The development of this branch of international law and of the normative content of the right to health, as well as the progressive clarification of the minimum obligations on States are, indeed, markers of progress which reveal and highlight the profound paradoxes between State's international commitments on the one hand, and State practices to protect and promote migrant access to healthcare on the other. On top of this, such progress permits more precise interpretations of the binding rules of international refugee and migrant law, rules that are unlikely to be renegotiated and which are couched in vague terms. In an era where international law is often flouted and where certain States are insensitive to the political pressure exerted by the international community, clarifying international human rights law is essential for the protection of migrants, regardless of their status, as well as, consequently, for the achievement of health for all in the $21^{\text {st }}$ century. 